\title{
The band fish Acanthocepola indica (Perciformes: Cepolidae) in the Northern Bay of Bengal, India
}

\author{
Alakesh Pradhan \& Bijay K. Mahapatra \\ ICAR-Central Institute of Fisheries Education, Kolkata Centre, Salt Lake, West Bengal, India; alakeshpradhan@gmail.com, \\ bkmahapatra@cife.edu.in
}

Received 10-VIII-2017 • Corrected 20-IX-2017 • Accepted 04-X-2017

\begin{abstract}
A relatively poorly known species of band fish, Acanthocepola indica (Cepolidae), is reported for the first time from the north-east coast of India, Bay of Bengal, based on single specimen $236,86 \mathrm{~mm}$ long, collected in Digha. We include a detailed, illustrated description of the specimen.
\end{abstract}

RESUMEN: Presencia del pez Acanthocepola indica (Perciformes: Cepolidae) en la Bahía del Norte de Bengala, India. Informamos la presencia de Acanthocepola indica (Cepolidae), en la Bahía de Bengala, a partir de un ejemplar de $236,83 \mathrm{~mm}$ de longitud, recolectada en Digha, e incluimos una descripción detallada.
The fishes of the family Cepolidae, commonly known as band fishes, comprise five genera with 66 species widely distributed in the tropical and subtropical seas throughout the world (Day, 1889; Smith, 1949; Shen, 1993; Heemstra, 1995; Froese \& Pauly, 2017). From these 66 species, 45 are currently considered valid species (Eschmeyer \& Fong, 2017), and 36 belong to the subfamily Owstoniinae and nine to the subfamily Cepolinae. Members of this family are associated with a variety of marine habitats such as sandy or muddy bottoms, and reefs at depths ranging between 40 and $300 \mathrm{~m}$ (Nakabo, 2002); usually found in $180-200 \mathrm{~m}$ depth. The members of the Cepolidae are of great interest for ichthyologists and aquarist due to their body shape, peculiar tail-burrowing nature and coloration patterns. There are numerous documentations, reports and studies carried out so far on ichthyofaunal diversity of West Bengal earlier (Manna \& Goswami, 1985; Goswami, 1992; Talwar, Mukherjee, Saha, Paul \& Kar, 1992; Chatterjee, Ramakrishna, Talukdar \& Mukherjee, 2000; Das et al., 2007; Sanyal, Alfred, Venkataraman, Tiwari \& Mitra, 2012; Venkataraman, RajkumarRanjan, Satyanarayana, Raghunathan \& Venkatraman, 2012; Mahapatra \& Lakra, 2015; Mahapatra
\& Pradhan, 2016; Pradhan \& Mahapatra, 2017), but none of them report the occurrence of $A$. indica in these waters. This species is reported here for the first time from the northern Bay of Bengal and its occurrence in West Bengal is confirmed.

One specimen of Acanthocepola indica (Day, 1888) [236,83mm in total length (TL); Fig. 1], was collected (Fig. 1), on 19 August 2016, by Mr. Alakesh Pradhan and Dr. B. K. Mahapatra, on a mechanized fishing vessel, in a trawl net at about 24 nautical miles from Digha coast of West Bengal, India $\left(21^{\circ} 37.843^{\prime} \mathrm{N}, 87^{\circ} 32.827^{\prime} \mathrm{E}\right)$, at $31 \mathrm{~m}$ of depth. The identification of the specimen was based on Day (1889), Masuda, Amaoka, Araga, Uyeno and Yoshino (1984), Smith-Vaniz (1986), Fischer and Bianchi (1994), Smith-Vaniz (2001), Eschmeyer, Fricke and van der Laan (2017) and Froese and Pauly (2017). Morphometric measurements of the specimen are given in Digital Appendix 1. The specimen was preserved in $10 \%$ formaldehyde and deposited in the Museum of ICAR-Central Institute of Fisheries Education, Kolkata Centre, Salt Lake (CIFE/ $\mathrm{KOL} / \mathrm{MW} / \mathrm{F0232}$ ). Other morphometric and meristic details of the specimen are given in the description section. 


\section{CEPOLIDAE Rafinesque, 1810}

Acanthocepola Bleeker, 1874

Acanthocepola indica Day, 1888

Cepola indica, Day, 1888 (p. 796)

Diagnosis: Body ribbon-like, caudal confluent with dorsal and anal fin. Head short, with blunt snout. Eyes large and high on head. Mouth large, oblique; upper jaw broad at end, without supra-maxilla, and extending to below posterior margin of eye; a single row of slightly curved teeth in jaws. Dorsal fin continuous, with 109 rays; anal fin with 98 rays; caudal fin pointed. Lateral line high on body, close to dorsal-fin base. Body uniformly orange-red or pink; anterior part of dorsal fin with a black blotch.

Detailed description: Body elongated, laterally compressed; gradually narrowing to caudal fin. Head short; $6,5 \mathrm{in} T L$, with blunt snout and 6 branchiostegal rays. Eyes comparatively large and high on head, 3,5in head length $(\mathrm{HL})$. Mouth large, oblique; gape wide; maxilla reaching the posterior margin of eye; a single row of slender, slightly curved canine teeth in each jaws. Posterior margin of pre-opercle serrated with 6 spines, one at angle of pre-opercle, one on the vertical, and four on the horizontal margin. Scales small cycloid in nature, but distinct, cheeks scaled, absent in opercles. Dorsal fin origin slightly behind orbit and middle of pectoral fin, with 109 unbranched rays; pre-dorsal length $8,8 \mathrm{in} \mathrm{TL}$, dorsal fin base
1,2 in TL; anal fin with 98 rays; pre-anal length 6,4in TL; pectoral fin well developed with 21 rays and its length more or less equal to pelvic fin length, elongated and not pointed, its length 1,7in $\mathrm{HL}$; dark outer edged dorsal and anal fins are confluent with caudal fin by a membrane, which is very hard and pointed; anterior part of dorsal fin with a black blotch between the seventh and eleventh dorsal fin rays. 151 total vertebrae, 11 pre-dorsal and 68 pre-anal vertebrae. Lateral line originate from upper margin of opercle and high on body, close to dorsal-fin base. Body uniformly orange-red or pink with many orange-yellow vertical lines (Fig. 2).

Distribution: Acanthocepola indica is known to occur inthe Indo-Western Pacific region through South Africa (Natal) (Heemstra, 1995), Taiwan (Shen, 1993), India and Japan. It is very rare and only found in Penghu Islands, western Taiwan.

Habitat: Acanthocepola indica is a bentho-pelagic fish usually found in shallow waters in a variety of marine habitats, including muddy and fine-sandyareas; rarely found in coral reef areas.

Remarks: The genus Acanthocepola is known to have about 4 species worldwide (Froese \& Pauly, 2017). The majority of these species have uniform body coloration, while others have distinct dark bands or spots. A. indica has a close resemblance with Acanthocepola limbata by
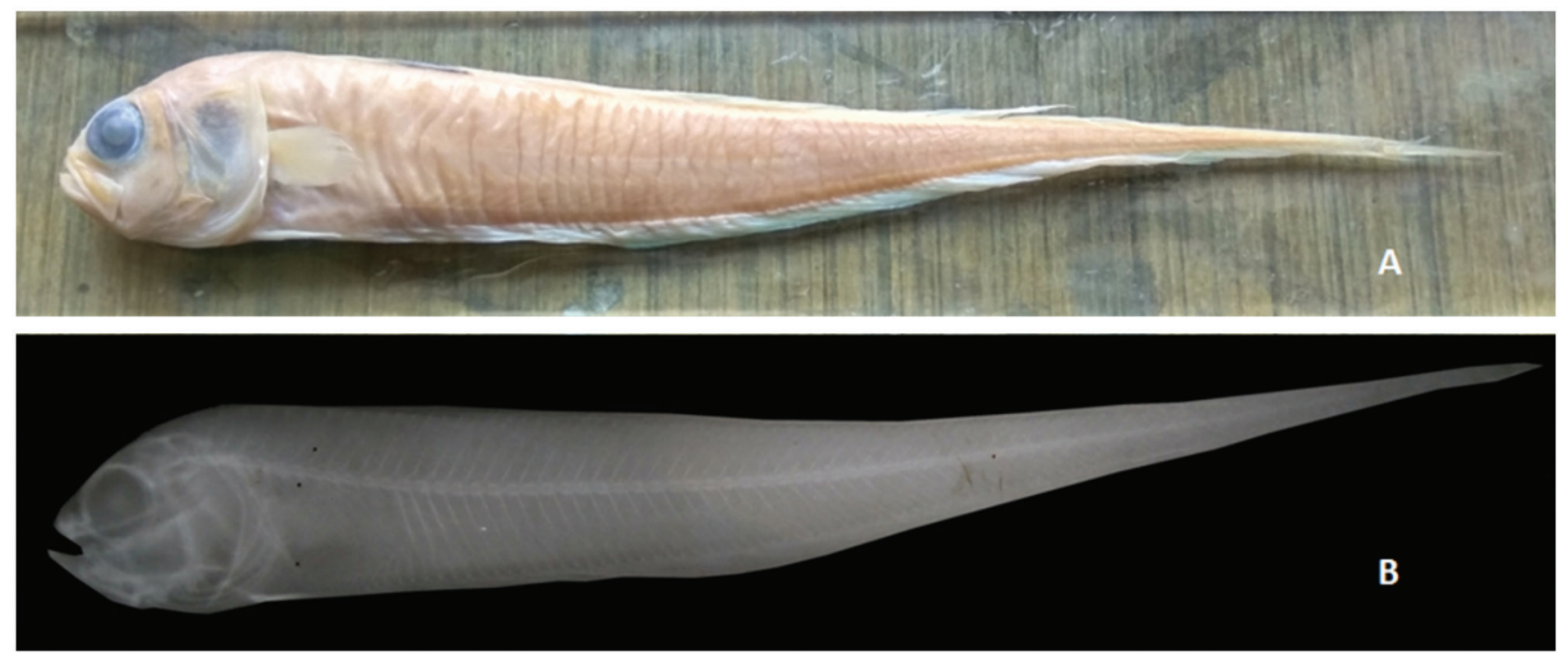

Fig. 1. (A) Preserved specimen and (B) x-ray Radiograph of A. indica from Northern Bay of Bengal, West Bengal, India (CIFE/KOL/MW/F0232; TL = 236,83mm) 

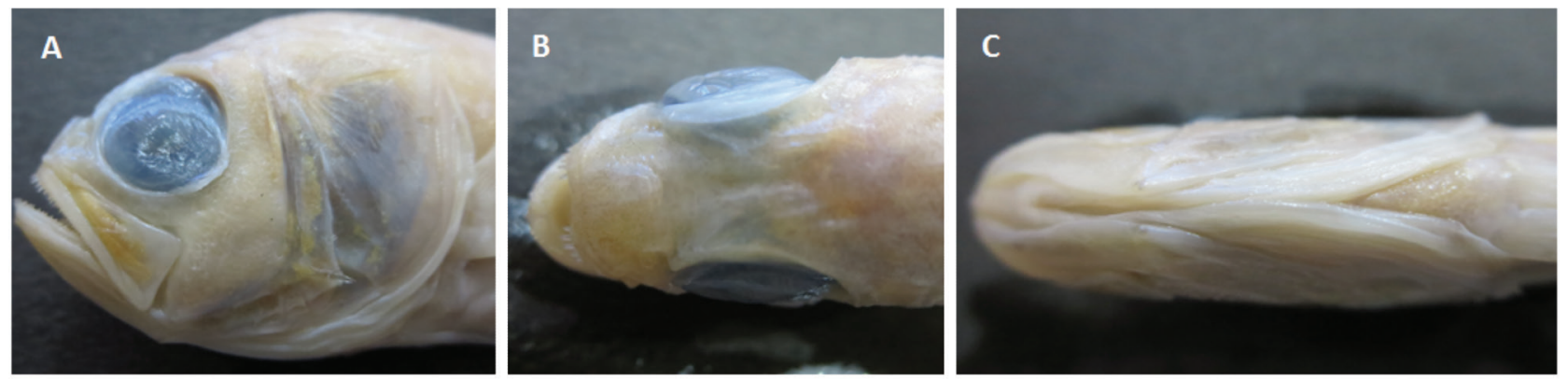

Fig. 2. (A) Lateral view of head and mouth; (B) dorsal view of inter-orbital ridge; and (C) ventral view of branchiostigal rays of $A$. indica from Northern Bay of Bengal, West Bengal, India (CIFE/KOL/MW/F0232; TL = 236,83mm)

certain morphological characters and by adult pigmentation. The characteristic of indistinct black blotch on anterior part of dorsal fin between the $7^{\text {th }}$ and $11^{\text {th }}$ dorsal fin rays of Acanthocepola indica separates it from $A$. limbata (dark red oblong blotch on the dorsal between $9^{\text {th }}$ and $14^{\text {th }}$ dorsal fin rays) and A. krusensternii (blotch absent). Acanthocepola abbreviata have lower number of dorsal fin (D. 67-74) and anal fin rays (A. 67-74) than $A$. indica (D. 109; A. 98).

Acanthocepola indica was described by Day (1888) as Cepola indica based on one specimen from Madras, India. As the species was originally described from India (Madras), so that the basic information documenting its occurrence in India. There was lacuna of information of this species and apparently, no one since then has reported this species from India. Hence, an attempt has been made in this paper to provide occurrence details and to confirm the presence of Acanthocepola indica on the east coast of India and an addition to the ichthyofaunal diversity of Bengal coastal waters. The detailed description of the species was also provided. The morphometric characters and meristic values of $A$. indica of the presently reported study match well those of the holotype in the original description.

\section{ACKNOWLEDGEMENTS}

The authors are greatly indebted to the Director, ICAR-CIFE, Mumbai for providing necessary facilities for the work. Authors are also thankful to David G. Smith (Smithsonian Institution, Museum Support Centre, Suitland, MD, USA for his valuable help in providing specific literature and information to prepare the manuscript.

\section{REFERENCES}

Chatterjee, T. K., Ramakrishna, Talukdar, S., \& Mukherjee, A. K. (2000). Fish and Fisheries of Digha coast of West Bengal. Zoological Survey of India, 188, 1-87.

Das, P., De, S. P., Bhowmik, R. M., Pandit, P. K., Sengupta, R., Nandi, A. C., Thakurta, S. C., \& Saha, S. (2007). Piscine diversity of West Bengal. Fishing Chimes, 27(5), 15-28.

Day, F. (1888). The fishes of India; being a natural history of the fishes known to inhabit the seas and fresh waters of India, Burma, and Ceylon. Fishes of India, Suppl., 779-816.

Day, F. (1889). Fauna of British India Fishes. London, England: Taylor and Francis.

Eschmeyer, W. N., Fricke, R., \& van der Laan, R. (Eds). (2017). Catalog of Fishes: Genera, Species, References. Retrieved from http://researcharchive.calacademy.org/research/ ichthyology/catalog/fishcatmain.asp

Eschmeyer, W. N., \& Fong, J. D. (2017). Species by family/subfamily. Retrieved from http://researcharchive.calacademy. org/research/ichthyology/catalog/SpeciesByFamily.asp

Fischer, W., \& Bianchi, G. (Eds). (1984). Western Indian Ocean (Fishing Area 51). FAO Species Identification Sheets for Fishery Purposes, 1-6.

Froese, R., \& Pauly, D. (2017). Species of Acanthocepola in FishBase. Retrieved from www.fishbase.org

Goswami, B. C. B. (1992). Marine fauna of Digha coast of West Bengal, India. Journal of the Marine Biological Association of India, 34(1-2), 115-137.

Heemstra, P. C. (1995). Additions and corrections for the 1995 impression. p. v-xv. In M.M. Smith \& P. C. Heemstra (eds.) Revised Edition of Smiths' Sea Fishes. Berlin, Germany: Springer.

Mahapatra, B. K., \& Lakra, W. S. (2015). Marine Ornamental Fish Biodiversity of West Bengal. Zoology, 4(8), 249-252. 
Mahapatra, B. K., \& Pradhan, A. (2016). Range extension and first report of the fish Lagocephalus inermis (Tetraodontiformes: Tetraodontidae) from Digha, North-east Coast of India. Cuadernos de Investigación UNED; 8(2), 201-205.

Manna, B., \& Goswami, B. C. B. (1985). A checklist of marine \& estuarine fishes of Digha, West Bengal, India. Mahasagar, 18(4), 489-499.

Masuda, H., Amaoka, K., Araga, C., Uyeno T., \& Yoshino, T. (1984). The fishes of the Japanese Archipelago. (v. 1): Text. (v. 2): Plate 192. Tokai University Press, Tokyo, Japan.

Nakabo, T. (2002). Fishes of Japan with pictorial keys to the species. English edition II. Japan: Tokai University Press, Japan.

Pradhan, A., \& Mahapatra, B. K. (2017). First record of the Two-Spot Razorfish, Iniistius bimaculatus (Perciformes: Labridae) from Digha, North-East Coast of India. Cuadernos de Investigación UNED, 9(1),115-118.

Sanyal, A. K., Alfred, J. R. B., Venkataraman, K., Tiwari, S. K., \& Mitra, S. (2012). Status of biodiversity of west Bengal: 1-969+35 Plates. Zoological Survey of India, 969.
Shen, S. C. (ed.). (1993). Fishes of Taiwan. Department of Zoology, National Taiwan University, Taipei.

Smith, J. L. B. (1949). The sea fishes of Southern Africa. Cape Town, South Africa: Central News Agency.

Smith-Vaniz, W. F. (1986). Cepolidae, In M. M. Smith, \& P. C. Heemstra (eds.). Smith's sea fishes. Berlin, German: Spinger.

Smith-Vaniz, W. F. (2001). Cepolidae, Bandfishes. In K. E Carpenter \& V. Niem (Eds.). FAO species identification guide for fishery purposes. The living marine resources of the Western Central Pacific. Bony fishes part 3 (Menidae to Pomacentridae). Rome, Italy: FAO.

Talwar, P. K., Mukherjee, P., Saha, D., Paul, S. N., \& Kar, S. (1992). Marine and estuarine fishes. Fauna of West Bengal State Fauna Series, 3, 243-342.

Venkataraman, K., RajkumarRanjan, Satyanarayana, Ch., Raghunathan, C., \& Venkatraman, C. (2012). Marine Ecosystems and Marine Protected Areas of India. Zoological Survey of India, 296. 